Article

\title{
Laser Irradiation Effects at Different Wavelengths on Phenology and Yield Components of Pretreated Maize Seed
}

\author{
Mohammed Hasan ${ }^{1}$, Marlia Mohd Hanafiah ${ }^{1,2, *}$, Ziad Aeyad Taha ${ }^{3}$, Intsar H. H. AlHilfy ${ }^{4}$ and \\ Mohd Nizam Mohd Said ${ }^{2}$ \\ 1 Department of Earth Sciences and Environment, Faculty of Science and Technology, Universiti Kebangsaan \\ Malaysia, Bangi 43600, Malaysia; aldulaimi89_fst@yahoo.com \\ 2 Centre for Tropical Climate Change System, Institute of Climate Change, Universiti Kebangsaan Malaysia, \\ Bangi 43600, Malaysia; m.n.said@ukm.edu.my \\ 3 Institute of Laser for Postgraduate Studies, University of Baghdad, Baghdad 00964, Iraq; \\ zddiesel@yahoo.com \\ 4 Department of Field Crop Science, College of Agriculture, University of Baghdad, Baghdad 00964, Iraq; \\ dr.intsar_hadi@yahoo.com \\ * Correspondence: mhmarlia@ukm.edu.my; Tel.: +603-89215865
}

Received: 12 January 2020; Accepted: 5 February 2020; Published: 10 February 2020

\begin{abstract}
This study aims to compare the effects of different laser wavelengths, exposure times, and low-power-intensity laser irradiation on maize seeds. Seeds were exposed to $\mathrm{He}-\mathrm{Ne}(632.8 \mathrm{~nm})$ red laser, Nd:YAG second-harmonic-generation $(532 \mathrm{~nm})$ green laser, and diode $(410 \mathrm{~nm})$ blue laser. Four different exposure times $(45,65,85$, and $105 \mathrm{~s})$ with different intensity $\left(2\right.$ and $\left.4 \mathrm{~mW} / \mathrm{cm}^{2}\right)$, for each laser were tested. Phenology and yield components (plant height, leaf area, number of rows per ear, seed yield, harvest index, yield efficiency, and grain weight) were determined. The experiment was conducted in a randomized complete block design with three replications. Plant height was found comparatively high in blue laser light-211 cm at $85 \mathrm{~s}$. Blue and green laser lights showed significant increases in the number of rows per ear to 39.1 at $85 \mathrm{~s}$ and 45 at $65 \mathrm{~s}$, respectively, compared to the control of 36 rows/ear. The order of seed yield was blue $(7003.4 \mathrm{~kg} / \mathrm{ha})>$ green $(6667.8 \mathrm{~kg} / \mathrm{ha})>$ red (6568.01 t/ha) based on different exposure times of $85 \mathrm{~s}, 85 \mathrm{~s}$, and $105 \mathrm{~s}$, respectively, compared to the control of $6.9 \mathrm{~kg} / \mathrm{ha}$. The findings indicate the possibility of using blue laser light to manipulate the growth and yield of maize.
\end{abstract}

Keywords: Zea mays L.; laser stimulation; yield components; wavelengths

\section{Introduction}

Laser technology can be a convenient option to be incorporated into systems of agricultural production. Therefore, more attention was given in recent years to physical factors that may be applicable to processing of sowing material [1,2]. In order to ensure a high seed performance, various methods of processing are used, including chemical preparations, such as seed inoculation by chemical material and growth regulators, as well as physical factors, including laser light and magnetic fields [3-8]. Pre-sowing treatment was applied in order to stimulate the seeds to better germinate and grow faster in various sowing conditions [9]. The use of physical factors for controlling the influence of biological behavior during development and storage of different cultures is a modern trend in combining the intensification of plant technologies with ecological requirements [10]. Most physical factors that only modify physiological and biochemical processes in seeds are also safe for the environment [11-13], for instance, improving agriculture practices, such as by using chemical 
fertilizer and regular weed control [14]; however, this can affect the environment [15]. In contrast, laser stimulation does not cause harmful changes in the environment, which is of great importance in organic and integrated agriculture [16,17].

Light is an essential condition for photosynthesis and is needed in plant improvement; it can also affect the seed field performance, growth, and yield of some plants [18-20]. Among the previously used methods of seed refining [21], light laser is a physical factor that does not cause adverse changes in the environment. Research on the effects of pre-sowing bio-stimulation on plant crops showed that the best results of this treatment are obtained for plant vegetables, rather than for cereals and root crops. After applying radiation laser to tomatoes and cucumbers, a significant increase in yield was found, which accelerated the ripening and produced better fruit quality $[8,22]$. One of the methods of seed refinement is irradiation; a divergent beam laser light provides energy to modify physiological and biochemical processes, causing an increase in the field's performance to rise and yield crops [23].

Previous work on the effects of pre-sowing seed stimulation with laser light concerned annual plants [24]. Laser stimulation is a physical phenomenon; it depends on its ability to absorb and store the light energy of plant cells and tissues. In the case of seeds, the same phenomenon can be observed; they absorb energy light, transform it into chemical energy, and use it at a later time [3].

The research conducted so far on the laser stimulation of plant seed agricultural and horticultural products shows that it may affect the enzymatic system, accelerating the decomposition of starch, the germination of seeds [25], photosynthesis, and transpiration efficiency $[10,26,27]$, as well as plant growth and development [28-30].

For this purpose, maize was selected as a model plant due to its significant economic value as a worldwide cultivated crop for its high starch content [31,32]. Furthermore, studies revealed that the laser is useful to improve the sanitary quality of maize seed [33]; this characteristic allows a seedling to have more strength to emerge from the soil [34].

The phenomenon of laser radiation is still poorly understood; there are only fragmentary studies or hypotheses that attempted to explain how laser light interacts with seeds [35-37]. So far, no studies were done on the effects of different wavelengths of laser light (i.e., blue, green, and red wavelengths) on maize seeds. Therefore, the aim of the study was to determine the effect of different doses and different wavelengths of laser irradiation for maize seeds during pre-sowing treatments in terms of yield value.

\section{Materials and Methods}

\subsection{Study Site}

The present study was carried out in 2018 at the experimental field located at the Faculty of Agriculture and Laser Laboratory at the Institute of Laser for Postgraduate Studies, University of

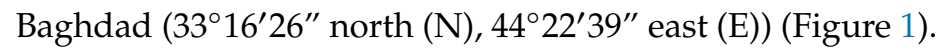

\subsection{Experimental Set-Up}

The lasers set-up was conducted at Laser Lab Institute of Laser for Postgraduate Studies (ILPS). The set-up structure of different laser devices included putting each laser in a special bed in the open part of the optical ruler, which provided good cooling conditions so that it could operate in a normal mode for an indefinite period of time. The laser devices for three different types of laser were provided separately by a metal stand, and silicone coating was applied to the front peripheral edge for better fixing contact. The optics were used to get the optimum power of the lasers. In addition, the intensity of the laser irradiation power was set at 2 and $4 \mathrm{~mW} / \mathrm{cm}^{2}$, which was measured by a power meter.

In fixing, the three laser irradiator mechanisms were designed to secure the continuation of the laser irradiation. They were fixed to a steady stand in specially designed beds in such a way that the total laser spot remained fixed. The collimation optics were mounted on the laboratory laser irradiators. 
The laser irradiation energy necessary for the pre-sowing seed irradiation was evenly distributed in compliance, with a total spot of $4 \mathrm{~mm}$ at a distance of $1 \mathrm{~m}$ from the laser fronts.
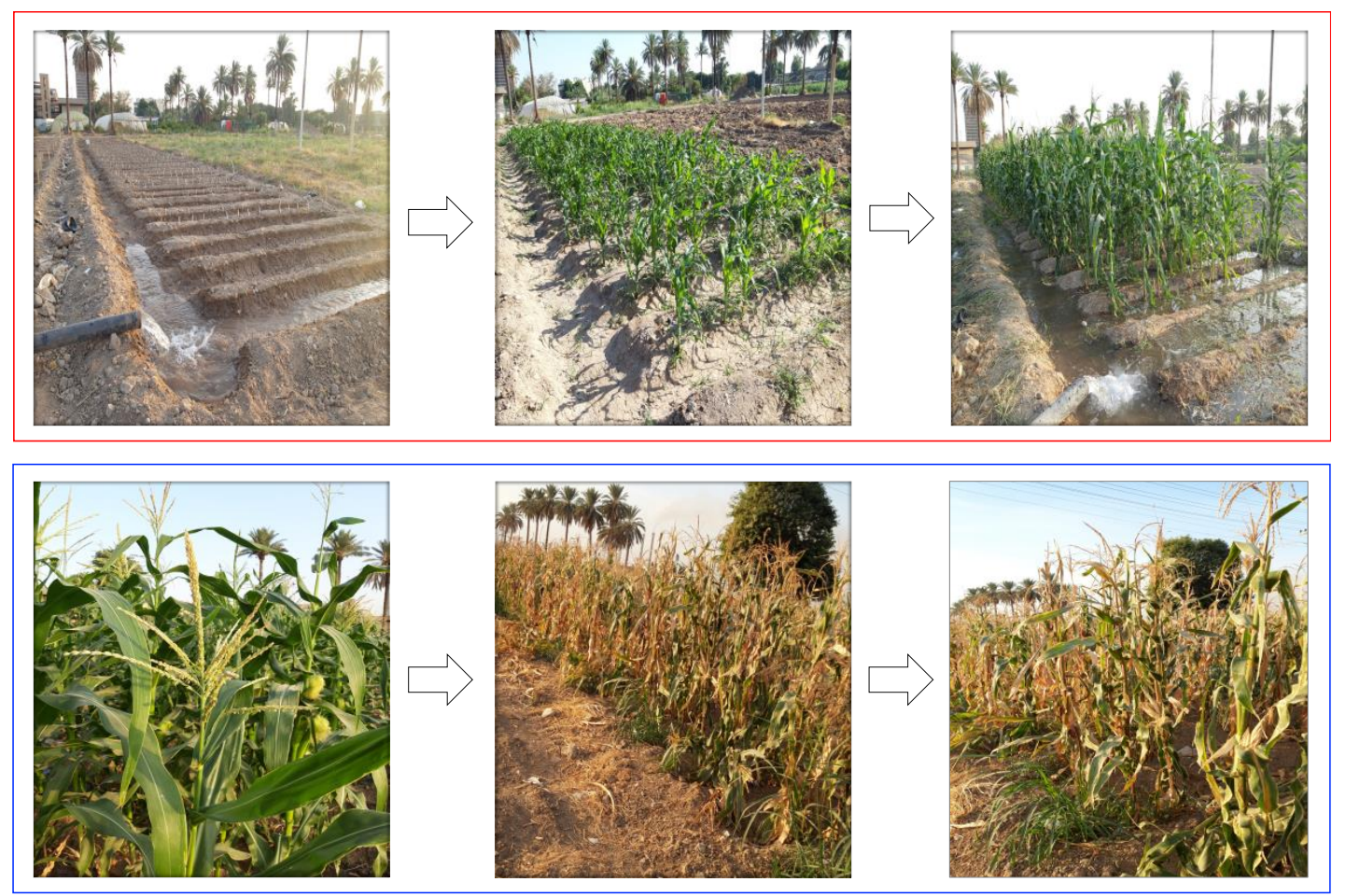

Figure 1. Red box: plant growth stages (sowing at field, emergence stage, and vegetative growth stage). Blue box: plant growth stages (flowering stage, maturity stage, and harvest stage).

Three types of laser were used: He-Ne (red), Nd:YAG second harmonic generation (green), and diode (blue), generated at $632.8,532$, and $410 \mathrm{~nm}$, respectively. The maize seeds were irradiated by the abovementioned lasers in exposure durations of 45, 65, 85, and $105 \mathrm{~s}$. A time controller device was used to get the optimum time for each treatment. The device parts and position of the treated samples are shown in Figure 2.
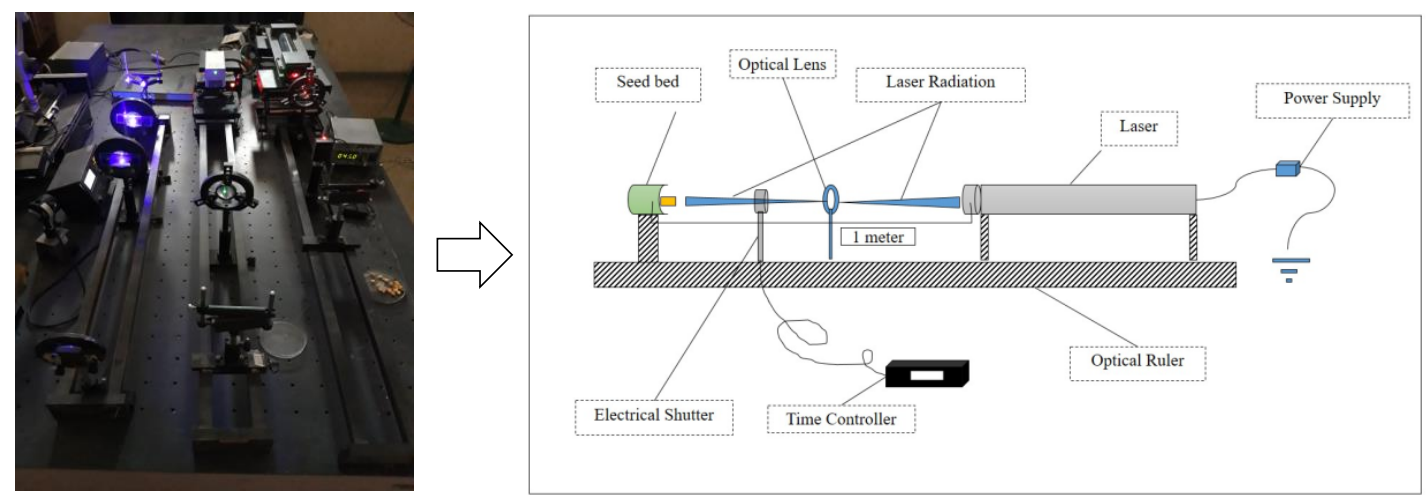

Figure 2. Set structure for the laser irradiation on maize seeds.

\subsection{UV-Visible Test}

The UV-visible analysis of samples was carried out using a UV-Vis Shimadzu Spectrophotometer (Shimadzu, Milton Keynes, UK) (UV-1800) to obtain the two statuses of wet and dry seed spectra, where the wet seed was moistened overnight by water before the analysis. Information was recorded using a silicon photodiode in the absorbance and transmittance mode with wavelength ranging from 
190 to $1100 \mathrm{~nm}$. Dry seeds were chosen for irradiation by the lasers due to absorbing more of the visible wavelength as compared to the wet seeds (Figure 3).
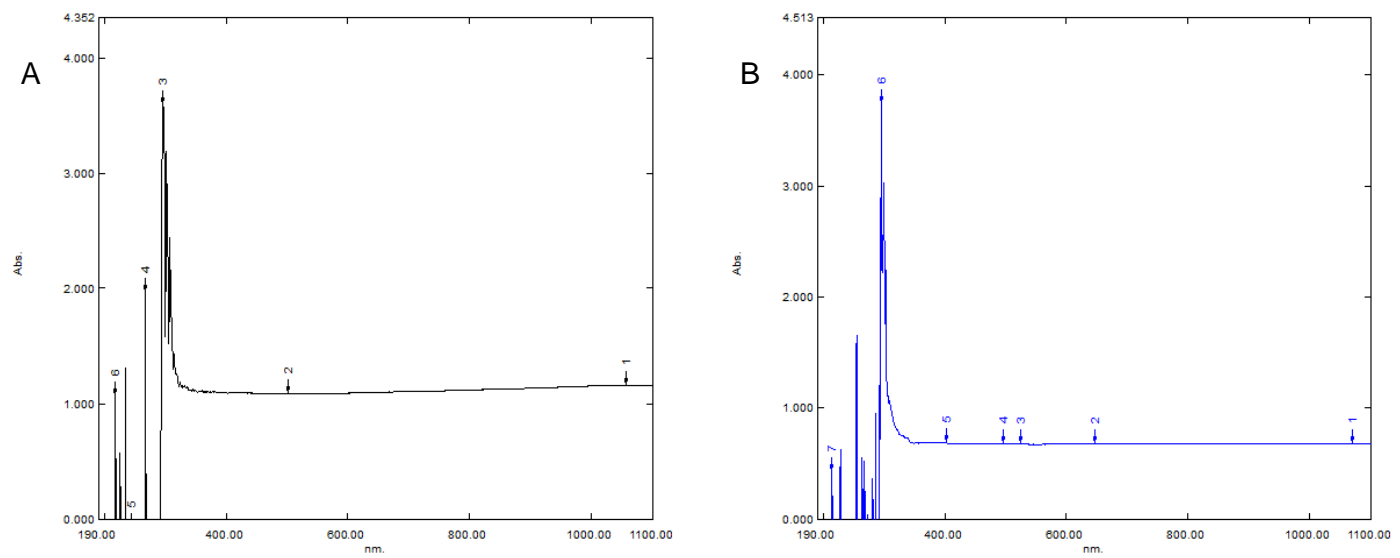

Figure 3. UV-visible analysis for two statuses of maize seed (dry (A) and wet (B)) by wavelength, ranging from $190-1100 \mathrm{~nm}$.

\subsection{Field Experiment}

The experiment was conducted with a randomized complete block design (RCBD) with three replications, three types of laser, four irradiation times, and two levels of laser intensity with control (without laser treatment) (24 treatment $\times 3$ replications). Field area was $6 \mathrm{~m} \times 25 \mathrm{~m}=300 \mathrm{~m}^{2}$, the total number of irradiated and planted seeds was 1200, and, after two weeks, the seeds thinned to 300 plants. The experimental field area was plowed in the fall. Fields were cultivated, disced, furrowed, and then plotted in early July 2018 before sowing the seeds. Soil samples were collected randomly from the field and then transferred to the lab to measure the physical-chemical parameters (Table 1). Fields were fertilized with $520 \mathrm{~kg} / \mathrm{ha}$ compost $\left(46: 18 \mathrm{~N}: \mathrm{P}_{2} \mathrm{O}_{5}\right)$, and, before sowing, the soil was fertilized by urea of $436 \mathrm{~kg} / \mathrm{ha}$ (half at 14 days after sowing and the rest at the flowering stage). The seeds were collected from the Office of Agriculture Research, and the variety used in this experiment was cultivar Baghdad 3; all seeds were filtered to have the same size. Before sowing, maize seeds were irradiated by three types of laser (red, green, and blue laser) for different exposure times-45, 65, 85, and 105 $\mathrm{s}$-and with two level of laser intensity $\left(4\right.$ and $\left.2 \mathrm{~mW} / \mathrm{cm}^{2}\right)$; additionally, seeds without irradiation were used as control plants. After laser treatment, the seeds were transferred to the field and sown at 4-5 $\mathrm{cm}$ depth with plant spacing of $30 \mathrm{~cm}$ length and $60 \mathrm{~cm}$ width. Irrigation was adjusted based on 80 $\mathrm{mm}$ of evaporation from pan class A and every five days during crop growth period. Weeds were hand-removed during growing seasons, and diazinon pesticide was used to control insects $(1.5 \mathrm{~kg} / \mathrm{ha})$, applied 20 and 35 days after sowing. Above ground, parts of the crop were harvested at 110 days (at maturity) from sowing.

Table 1. Initial physical and chemical properties of the experimental soil.

\begin{tabular}{cc}
\hline Parameters & Value \\
\hline $\mathrm{pH}$ & 7.2 \\
Electrical conductivity meq/100g soil & 3.8 \\
Potassium (mg/L) & 1.6 \\
Phosphorus (mg/kg soil) & 43.2 \\
Silt (g/kg soil) & 28.9 \\
Clay (g/kg soil) & 38.5 \\
Sand (g/kg soil) & 32.6 \\
Nitrate (\%) & 0.0017 \\
Ammonia nitrogen (\%) & 0.009 \\
Texture & Silty clay \\
\hline
\end{tabular}




\subsection{Experimental Parameters}

Data were recorded for phenology (physiological maturity) and yield components (plant height, leaf area, number of rows per ear, seed yield, harvest index, yield efficiency, and grain weight). From each treatment, 10 ears were selected; plant length and the number of rows per ear were calculated and then averaged. Grain weight was determined by weighing 300 grains, randomly taken from the grain lot of each subplot. This was repeated three times in order to calculate the average grain weight. At maturity, 10 plants from each subplot were harvested. Ears were dried, shelled, and weighed. Grain yield was expressed in $\mathrm{kg} \cdot \mathrm{ha}^{-1}$ at the moisture ratio of $15 \%$. The harvest index was calculated according to the following formula: harvest index $(\%)=$ grain yield/biological yield $\times 100$. The yield efficiency was calculated by grain yield/leaf area, and the leaf area was measured [38] using the following formula: leaf area $=(\text { length leaf })^{2} \times 0.75$.

\subsection{Statistical Analysis}

Genstat ${ }^{\circledR}$ Statistical software version 19 was used to analyze the data by applying an analysis of variance (ANOVA) at a probability of $p<0.01$; significant differences among means were defined using the Fisher's test. All measurements were carried out in triplicate.

\section{Results and Discussion}

The effects of laser application on the plant height parameters of maize are shown in Table 2. Laser treatment significantly affected plant height of maize, along with different exposure time and power density. Generally, laser treatment increased plant height, as compared to those seeds without treatment (control). The pre-sowing irradiation of blue laser for $85 \mathrm{~s}$ at $4 \mathrm{~mW} / \mathrm{cm}^{2}$ significantly increased the plant height $(211 \mathrm{~cm})$ with respect to the seedlings from the control seeds $(201 \mathrm{~cm})$. A similar trend was observed for the red laser (Table 2), and the highest plant height $(207 \mathrm{~cm})$ resulted from $105 \mathrm{~s}$ of exposure in $2 \mathrm{~mW} / \mathrm{cm}^{2}$ as compared to the control seeds.

Table 2. Growth and yield component of maize seeds pretreated with lasers of different wavelength and exposure times.

\begin{tabular}{|c|c|c|c|c|c|c|c|}
\hline Treatments & $\begin{array}{c}\text { No. of } \\
\text { Row (ear) }\end{array}$ & $\begin{array}{c}\text { Leaf Area } \\
\left(\mathrm{cm}^{2}\right)\end{array}$ & $\begin{array}{l}\text { Plant Height } \\
\text { (cm) }\end{array}$ & $\begin{array}{l}\text { Weight of } 300 \\
\text { Seed (g) }\end{array}$ & $\begin{array}{l}\text { Seed Yield } \\
\text { (kg/ha) }\end{array}$ & $\begin{array}{c}\text { Harvest } \\
\text { Index (\%) }\end{array}$ & $\begin{array}{l}\text { Yield Efficiency } \\
\qquad\left(\mathrm{g} / \mathrm{cm}^{2}\right)\end{array}$ \\
\hline \multicolumn{8}{|c|}{ Red laser } \\
\hline $\mathrm{L}_{1} \mathrm{~T}_{1} \mathrm{~S}_{1}$ & $22.5^{\mathrm{i}, \mathrm{h}}$ & $435.0^{i, j}$ & $192^{g-j}$ & $53.21^{\mathrm{a}}$ & $4744.57^{\mathrm{k}}$ & $21.6^{\mathrm{a}}$ & $12.02^{1}$ \\
\hline $\mathrm{L}_{1} \mathrm{~T}_{1} \mathrm{~S}_{2}$ & $28.5^{\mathrm{g}}$ & $457.5^{f, g}$ & $197^{\mathrm{e}-\mathrm{h}}$ & $52.0^{\mathrm{a}}$ & $5370.53^{i-k}$ & $21.3^{\mathrm{a}}$ & $12.94^{\mathrm{i}-1}$ \\
\hline $\mathrm{L}_{1} \mathrm{~T}_{2} \mathrm{~S}_{1}$ & $22.5^{i, j}$ & $397.5^{\mathrm{m}}$ & $201^{b-f}$ & $54.0^{\mathrm{a}}$ & $5724.33^{\mathrm{f}-\mathrm{i}}$ & $20.9^{\mathrm{a}}$ & $15.87^{\mathrm{a}-\mathrm{d}}$ \\
\hline $\mathrm{L}_{1} \mathrm{~T}_{2} \mathrm{~S}_{2}$ & $34.5^{\mathrm{d}, \mathrm{e}}$ & $480.0^{c, d}$ & $204^{b-d}$ & $55.0^{\mathrm{a}}$ & $5597.33^{h-j}$ & $22.4^{\mathrm{a}}$ & $12.85^{\mathrm{i}-1}$ \\
\hline $\mathrm{L}_{1} \mathrm{~T}_{3} \mathrm{~S}_{1}$ & $31.0^{\mathrm{f}}$ & $472.5^{\mathrm{d}, \mathrm{e}}$ & $192^{g-j}$ & $51.0^{\mathrm{a}}$ & $5787.83^{\mathrm{e}-\mathrm{i}}$ & $22.9^{\mathrm{a}}$ & $13.09^{\mathrm{i}-1}$ \\
\hline $\mathrm{L}_{1} \mathrm{~T}_{3} \mathrm{~S}_{2}$ & $34.5^{\mathrm{d}, \mathrm{e}}$ & $442.5^{\mathrm{h}, \mathrm{i}}$ & $196^{\mathrm{f}-\mathrm{i}}$ & $52.3^{\mathrm{a}}$ & $4889.72^{\mathrm{j}, \mathrm{k}}$ & $22.1^{\mathrm{a}}$ & $12.18^{\mathrm{k}, \mathrm{l}}$ \\
\hline $\mathrm{L}_{1} \mathrm{~T}_{4} \mathrm{~S}_{1}$ & $30.5^{f, g}$ & $412.5^{1}$ & $200^{c-f}$ & $52.9^{a}$ & $6323.07^{a-g}$ & $21.7^{\mathrm{a}}$ & $16.9^{\mathrm{a}, \mathrm{b}}$ \\
\hline $\mathrm{L}_{1} \mathrm{~T}_{4} \mathrm{~S}_{2}$ & $21.5^{\mathrm{j}}$ & $450.0^{\mathrm{g}, \mathrm{h}}$ & $207^{\mathrm{a}}$ & $51.0^{\mathrm{a}}$ & $6568.01^{a-d}$ & $22.3^{\mathrm{a}}$ & $16.09^{a-d}$ \\
\hline \multicolumn{8}{|c|}{ Green laser } \\
\hline $\mathrm{L}_{2} \mathrm{~T}_{1} \mathrm{~S}_{1}$ & $25.5^{\mathrm{h}}$ & $465.0^{\mathrm{e}, \mathrm{f}}$ & $203^{b-e}$ & $54.2^{\mathrm{a}}$ & $6368.43^{a-f}$ & $21.8^{\mathrm{a}}$ & $15.1^{b-h}$ \\
\hline $\mathrm{L}_{2} \mathrm{~T}_{1} \mathrm{~S}_{2}$ & $29.0^{f, g}$ & $427.5^{\mathrm{j}, \mathrm{k}}$ & $199^{c-f}$ & $54.8^{\mathrm{a}}$ & $6286.79^{a-h}$ & $20.2^{a}$ & $16.21^{a-c}$ \\
\hline $\mathrm{L}_{2} \mathrm{~T}_{2} \mathrm{~S}_{1}$ & $40.0^{\mathrm{a}}$ & $442.5^{\mathrm{h}, \mathrm{i}}$ & $203^{b-e}$ & $53.2^{\mathrm{a}}$ & $6885.53^{a-c}$ & $22.1^{\mathrm{a}}$ & $16.86^{a, b}$ \\
\hline $\mathrm{L}_{2} \mathrm{~T}_{2} \mathrm{~S}_{2}$ & $37.5^{b, c}$ & $472.5^{\mathrm{d}, \mathrm{e}}$ & $189^{\mathrm{i}}$ & $51.2^{\mathrm{a}}$ & $5415.89^{i-k}$ & $20.7^{a}$ & $12.63^{\mathrm{j}-1}$ \\
\hline $\mathrm{L}_{2} \mathrm{~T}_{3} \mathrm{~S}_{1}$ & $20.5^{j}$ & $472.5^{\mathrm{d}, \mathrm{e}}$ & $190^{\mathrm{i}, j}$ & $53.1^{\mathrm{a}}$ & $5660.8^{f-i}$ & $20.9^{a}$ & $13.21^{\mathrm{i}-1}$ \\
\hline $\mathrm{L}_{2} \mathrm{~T}_{3} \mathrm{~S}_{2}$ & $30.0^{\mathrm{f}, \mathrm{g}}$ & $420.0^{\mathrm{k}, \mathrm{l}}$ & $202^{b-f}$ & $53.9^{a}$ & $6667.8^{a-c}$ & $21.7^{\mathrm{a}}$ & $17.5^{\mathrm{a}}$ \\
\hline $\mathrm{L}_{2} \mathrm{~T}_{4} \mathrm{~S}_{1}$ & $28.5 \mathrm{~g}$ & $495.0^{\mathrm{b}}$ & $191^{\mathrm{h}-\mathrm{j}}$ & $51.7^{\mathrm{a}}$ & $6205.1^{\mathrm{c}-\mathrm{h}}$ & $22.3^{a}$ & $13.82^{f-1}$ \\
\hline $\mathrm{L}_{2} \mathrm{~T}_{4} \mathrm{~S}_{2}$ & $26.0^{h}$ & $450.0^{\mathrm{g}, \mathrm{h}}$ & $205^{a-c}$ & $53.6^{a}$ & $5923.9^{\mathrm{d}-\mathrm{i}}$ & $22.2^{\mathrm{a}}$ & $13.61^{\mathrm{g}-1}$ \\
\hline
\end{tabular}


Table 2. Cont.

\begin{tabular}{|c|c|c|c|c|c|c|c|}
\hline Treatments & $\begin{array}{c}\text { No. of } \\
\text { Row (ear) }\end{array}$ & $\begin{array}{l}\text { Leaf Area } \\
\left(\mathrm{cm}^{2}\right)\end{array}$ & $\begin{array}{l}\text { Plant Height } \\
(\mathrm{cm})\end{array}$ & $\begin{array}{l}\text { Weight of } 300 \\
\text { Seed }(\mathrm{g})\end{array}$ & $\begin{array}{l}\text { Seed Yield } \\
\text { (kg/ha) }\end{array}$ & $\begin{array}{c}\text { Harvest } \\
\text { Index }(\%)\end{array}$ & $\begin{array}{l}\text { Yield Efficiency } \\
\qquad\left(\mathrm{g} / \mathrm{cm}^{2}\right)\end{array}$ \\
\hline \multicolumn{8}{|c|}{ Blue laser } \\
\hline $\mathrm{L}_{3} \mathrm{~T}_{1} \mathrm{~S}_{1}$ & $30.5^{f, g}$ & $435.0^{\mathrm{i}, \mathrm{j}}$ & $198^{\mathrm{d}-\mathrm{g}}$ & $52.8^{a}$ & $5279.8^{i-k}$ & $21.8^{a}$ & $13.38^{\mathrm{h}-\mathrm{l}}$ \\
\hline $\mathrm{L}_{3} \mathrm{~T}_{1} \mathrm{~S}_{2}$ & $36.0^{c-e}$ & $442.5^{h, i}$ & $202^{b-f}$ & $53.3^{a}$ & $5615.4^{g-i}$ & $22^{a}$ & $13.99^{\mathrm{e}-\mathrm{k}}$ \\
\hline $\mathrm{L}_{3} \mathrm{~T}_{2} \mathrm{~S}_{1}$ & $24.0^{h, i}$ & $480.0^{\mathrm{c}, \mathrm{d}}$ & $197^{\mathrm{e}-\mathrm{h}}$ & $52.1^{a}$ & $5352 . .3^{i-k}$ & $23.1^{a}$ & $12.29^{\mathrm{k}, 1}$ \\
\hline $\mathrm{L}_{3} \mathrm{~T}_{2} \mathrm{~S}_{2}$ & $24.0^{h, i}$ & $457.5^{\mathrm{f}, \mathrm{g}}$ & $189.3^{i, j}$ & $53.4^{\mathrm{a}}$ & $6468.2^{a-e}$ & $22.8^{a}$ & $15.58^{b-f}$ \\
\hline $\mathrm{L}_{3} \mathrm{~T}_{3} \mathrm{~S}_{1}$ & $39.1^{a, b}$ & $510.0^{a}$ & $211^{a}$ & $53.7^{\mathrm{a}}$ & $7003.4^{a}$ & $23.6^{a}$ & $15.14^{\mathrm{b}-\mathrm{h}}$ \\
\hline $\mathrm{L}_{3} \mathrm{~T}_{3} \mathrm{~S}_{2}$ & $38.0^{a-c}$ & $517.5^{a}$ & $207^{a}$ & $55.3^{a}$ & $6939.9^{a, b}$ & $22.9^{a}$ & $14.38^{\mathrm{d}-\mathrm{j}}$ \\
\hline $\mathrm{L}_{3} \mathrm{~T}_{4} \mathrm{~S}_{1}$ & $29.5^{f, g}$ & $435.0^{i, j}$ & $200^{c-f}$ & $54.9^{a}$ & $6232.3^{b-h}$ & $21.9^{a}$ & $15.79^{a-e}$ \\
\hline $\mathrm{L}_{3} \mathrm{~T}_{4} \mathrm{~S}_{2}$ & $34.0^{\mathrm{e}}$ & $450.0^{\mathrm{g}, \mathrm{h}}$ & $196^{\mathrm{f}-\mathrm{h}}$ & $51.5^{a}$ & $5833.1^{\mathrm{e}-\mathrm{i}}$ & $22.2^{a}$ & $15.33^{\mathrm{b}-\mathrm{g}}$ \\
\hline Control & $36.5^{c, d}$ & $487.5^{b, c}$ & $201^{b-f}$ & $52.7^{a}$ & $6259.5^{b-h}$ & $20.7^{a}$ & $14.51^{\mathrm{c}-\mathrm{i}}$ \\
\hline \multicolumn{8}{|c|}{ Interaction } \\
\hline $\mathrm{L}$ & $* *$ & ** & $\mathrm{Ns}$ & Ns & ** & Ns & Ns \\
\hline $\mathrm{T}$ & $* *$ & $* *$ & Ns & Ns & $* *$ & Ns & $* *$ \\
\hline S & $* *$ & Ns & Ns & Ns & Ns & Ns & Ns \\
\hline $\mathrm{L} \times \mathrm{T}$ & $* *$ & $* *$ & $* *$ & Ns & $* *$ & Ns & $* *$ \\
\hline $\mathrm{L} \times \mathrm{S}$ & Ns & $* *$ & $* *$ & Ns & Ns & Ns & Ns \\
\hline $\mathrm{T} \times \mathrm{S}$ & $* *$ & $* *$ & $* *$ & Ns & Ns & Ns & $* *$ \\
\hline $\mathrm{L} \times \mathrm{T} \times \mathrm{S}$ & $* *$ & $* *$ & $* *$ & Ns & $* *$ & Ns & $* *$ \\
\hline
\end{tabular}

Laser types: $\mathrm{L}_{1}=$ red, $\mathrm{L}_{2}=$ green, and $\mathrm{L}_{3}=$ blue. Exposure time: $\mathrm{T}_{1}=45 \mathrm{~s}, \mathrm{~T}_{2}=65 \mathrm{~s}, \mathrm{~T}_{3}=85 \mathrm{~s}$, and $\mathrm{T}_{4}=105 \mathrm{~s}$. Power density: $\mathrm{S}_{1}=4 \mathrm{~mW} / \mathrm{cm}^{2}$, and $\mathrm{S}_{2}=2 \mathrm{~mW} / \mathrm{cm}^{2}$. Means of treatments were compared using the least significant difference (LSD) at $p \leq 0.01$. ${ }^{* *}=$ significant difference at $p \leq 0.01$. a-l $=$ Mean values with the same letters are statistically equal (Fisher's, $\alpha=0.01$ ); Ns = not significant.

The laser treatments also significantly affected the number of rows per ears of maize, as shown in Table 2. Increases in the number of rows per ears for both power densities were noted. The best results (40 rows/ear) were obtained from the exposure time of $65 \mathrm{~s}$ at $4 \mathrm{~mW} / \mathrm{cm}^{2}$ with the green laser, followed by $85 \mathrm{~s}$ at $4 \mathrm{~mW} / \mathrm{cm}^{2}$ for the seed irradiated with the blue laser (39.1 rows/ear). The minimum number of rows per ears (20.5) was obtained with green laser at $85 \mathrm{~s}$ at $4 \mathrm{~mW} / \mathrm{cm}^{2}$. In the case of the leaf area, data in Table 2 showed significant differences when using various lasers and exposure times. A significant leaf size ( 517.5 and $510 \mathrm{~cm}^{2}$ ) was obtained by the blue laser for exposure time of $85 \mathrm{~s}$ and laser power at 2 and $4 \mathrm{~mW} / \mathrm{cm}^{2}$, respectively, whereas the leaf size for the unexposed control plant was recorded as $487.5 \mathrm{~cm}^{2}$.

The present study shows that most of the parameters (number or rows/ear, plant height, leaf area, seed yield, and yield efficiency) were significantly affected, except for weight of 300 seed and harvest index. Yet, low-radiation dose intensity activates the plants, resulting in an increase in the bio-energetic potential of the cells and greater activation of their biochemical and physiological processes, while high doses of irradiation influence the genetic material of cells, causing genetic changes in the plants [39].

A significantly larger leaf area was observed for the plants treated by the blue laser during the harvesting stage due to the increase in the photosynthesis activity, which, in turn, led to an increase in the leaf surface area of maize, as compared to the un-irradiated seeds (control). However, there was no significant effect on the leaf area for the seeds irradiated by various laser treatments. There was also an increase in the number of rows per ears as a result of an increase in the surface area of one leaf or an increase in the number of leaves per plant. In both cases, this led to an increase in the productivity of photosynthesis. Morphological changes in the plants grown from the seeds treated by $\mathrm{He}-\mathrm{Ne}$ laser light of $50 \mathrm{~mW}$ were observed; they were taller and thicker than plants from seeds without irradiation (control), as reported by Srećković et al. [40]. Recently, some research studies were carried out on different light intensities and their effect on phases of plant growth [22,41,42]. Bio-stimulation using $\mathrm{He}-\mathrm{Ne}$ laser and laser diodes was applied to improve the physiological quality of certain crops [16].

Hence, only a few studies were conducted on the influence of laser light on the formation of physiological indicators of plant productivity; this makes it difficult to compare the results obtained by 
the present study with the results of other studies. The synergy of simultaneous events that happen when the seed is irradiated by laser light makes the mechanisms of bio-stimulation unclear [23]. Yet, tomato seeds (Solanum lycopersicum L.) were studied by applying a laser of $25 \mathrm{~mW}$ with exposure times of 5, 10, 20, 30, and $60 \mathrm{~s}$ [20]. It was found that the height of the plants showed a significant difference with respect to control (non-irradiated) samples.

Our results were confirmed by Abu Elsaoud and Tuleukhanov [43], whose study found that seeds pretreated with a laser $\left(I=5 \mathrm{~mW} / \mathrm{mm}^{2}\right)$ significantly increased the germination and growth parameters of four wheat varieties after seven days of treatment. Muthusamy et al. [44] applied treatment of low-intensity laser light at different irradiation doses on eggplant seeds (Solanum melongena L.) and observed significant changes in later growth stage and yield; the best results were found radiation doses of 25 and $30 \mathrm{~mJ} / \mathrm{cm}^{2}$. The highest value of stimulation in the height of the plants was obtained at $\mathrm{t}=20 \mathrm{~s}$, with significantly increased growth (stem diameter, root length, and height of plants) for the exposure times of 5, 10, and $20 \mathrm{~s} \mathrm{[45].}$

The exposure of maize seeds for $85 \mathrm{~s}$ with $2 \mathrm{~mW} / \mathrm{cm}^{2}$ power density of blue laser increased the weight of 300 seed ( $55.3 \mathrm{~g}$ ); however, compared to the control ( $52.7 \mathrm{~g})$, there was no significant difference (Table 2). The yield of maize seed ( $\mathrm{t} / \mathrm{ha}$ ), as shown in Table 3, exhibited significant differences. In general, using different wavelengths with different exposure times led to an increase in the seed yield. For the blue laser, $85 \mathrm{~s}$ of exposure in $4 \mathrm{~mW} / \mathrm{cm}^{2}$ had higher yield $(7003.4 \mathrm{~kg} / \mathrm{ha})$, followed by seeds irradiated with power density $2 \mathrm{~mW} / \mathrm{cm}^{2}(6939.9 \mathrm{~kg} / \mathrm{ha})$, which significantly increased yield compared to control $(6259.5 \mathrm{~kg} / \mathrm{ha})$. However, the application of different lasers at both powers with different exposure times significantly increased the yield efficiency $\left(\mathrm{g} / \mathrm{cm}^{2}\right)$ for maize seeds (Table 2). As a general trend, increasing exposure time using the green laser led to a remarkable increase in yield efficiency. The maximum yield efficiency $\left(17.5 \mathrm{~g} / \mathrm{cm}^{2}\right)$ of different types of lasers was obtained with exposure ( $85 \mathrm{~s}$ ) to the green laser for $2 \mathrm{~mW} / \mathrm{cm}^{2}$ followed by $16.9 \mathrm{~g} / \mathrm{cm}^{2}$ exposure to the He-Ne laser in seeds irradiated for $105 \mathrm{~s}$ combined with power $4 \mathrm{mw} / \mathrm{cm}^{2}$. The control (unexposed) group resulted in yield efficiency of $14.5 \mathrm{~g} / \mathrm{cm}^{2}$.

The values of the harvest index (\%) of maize, as shown in Table 2, showed that all different laser types and the various exposure times resulted in a marked increase in the harvest index, but no significant effect was observed according to statistical analysis. The highest value, $23.6 \%$, was obtained from the third exposure time $(85 \mathrm{~s})$ of the blue laser at $4 \mathrm{~mW} / \mathrm{cm}^{2}$, as compared to the control group, which exhibited the lowest harvest index percentage (20.7\%). The irradiation of the maize seeds by various lasers and exposure times had a significant influence on the harvesting index and yield efficiency. Hence, in the case of the seeds irradiated by the blue laser, an increase in yield was due to a change in other growth and yield-generating features.

Furthermore, Álvarez et al. [22] found that laser bio-stimulation of tomatoes increased the number of flowers, fruits, bunches, polar mean diameter, equatorial mean diameter, weight of the fruits, and yield per plant. However, Sánchez et al. [41] indicated a positive bio-stimulation in bean seeds, which were irradiated by blue laser and obtained an enhancement of $47 \%$ in germination as compared to the control sample. Jakubiak and Gdowska [21] found that laser irradiation accelerates the growth and biomass of willow varieties (Salix sp.).

Similarly, the effects of the spectral impact of the laser on seed performance were reported [27]; laser irradiation induces a change in the plant development and makes the cell divide faster, which results in faster initial rate of growth and improvement. Therefore, the significant effect of laser light on growth and yield parameters in the present study could have been due to an increase in cell division. Jevtić et al. [9] found that irradiating wheat seeds with laser in dry and humid conditions produced greater yield, as compared to non-irradiated seeds (control). The best efficiency was obtained with the 532-nm laser at two regimes of irradiation, with the effects of bio-stimulation being more evident at a higher salt concentration [46]. Irradiation with laser could be an alternative to control diseases in maize seeds (Zea mays L.) and, in this way, could improve the sanitary quality of the seed and possibly of the final product obtained from the plants with seeds treated with a laser. Likewise, Reyes et al. [5] found 
that, for barley seeds (Hordeum vulgare L.), all exposure times showed an improvement in the sanitary quality of the seed. Using a laser diode produced significant statistical differences in germination, as well as in performance, for maize seeds [47].

In the present study, the pre-sowing seeds irradiated with blue $(410 \mathrm{~nm})$, red $(632.8 \mathrm{~nm})$, and green $(532 \mathrm{~nm})$ laser lights had significant effects on the seed yield and the harvesting index characteristics of the plant. The results of seed yield indicated that the blue laser light had a better influence on maize seed than without the light condition (the control experiment), whereas the influence of the blue laser light was higher than the other laser lights used. Long irradiation times and high wavelength can cause considerable damage to the seed structures. Furthermore, laser stimulation is a physical phenomenon that consists of absorbing and storing radiant energy by plant cells and tissues. The same phenomenon can be observed in the case of seeds when they first absorb the radiation energy and then transform it into chemical energy and use it for subsequent growth [48].

The basis of laser stimulation mechanisms in some physiological states of plants is synergism between the monochromatic and polarized laser light beam and the photoreceptors of light. The irradiation effect of the maize sowing seeds stimulates an increase in seed yield. An analysis of the yield structure showed that an increase in maize yield resulted from an increase in row number per ear, which, in maize, is the property that most often changes due to the activity of other yield-generating factors; the number of seeds per ear was the least changeable property. In the bio-stimulation of plants in their different phases of development, three classes of photoreceptors were discovered: phytochromes, phototropins, and cryptochromes. These photoreceptors absorbed different wavelengths, i.e., $600-750$, $320-500$, and 500-630 nm, respectively [49-52]. One of the hypotheses about the energy absorption by the seeds is that light is absorbed by different crop stages in their life cycle; the light is then transformed into chemical energy, and the seeds use it for their subsequent growth processes [53]. Evidence of thermal changes due to laser irradiation was demonstrated by Hernández-Aguilar et al. [41], where an irradiated maize seed was placed in different containers. They found that the temperature of the seed was modified according to the optical and thermal properties of the seeds; it also depended on the container on which the seed was placed.

A laser with a wavelength of $532 \mathrm{~nm}$ and $25 \mathrm{~mW}$ of power was applied in soybeans (Glycine max), resulting in early emergence during germination when compared with the control group [54]. The vegetative growth of soybean seedlings was significantly higher after laser treatment; the magnitude of the stimulation for seedling growth was a function of the time exposed to laser treatment [17]. Rassam et al. [55] stated that laser treatment could be used to control the fungal infection in wheat seeds and improve their growth and development. Table 3 summarizes the progress of studies on the effects of lasers on maize according to recent studies.

Table 3. Presenting the bio-effects of low-intensity laser light in maize seeds.

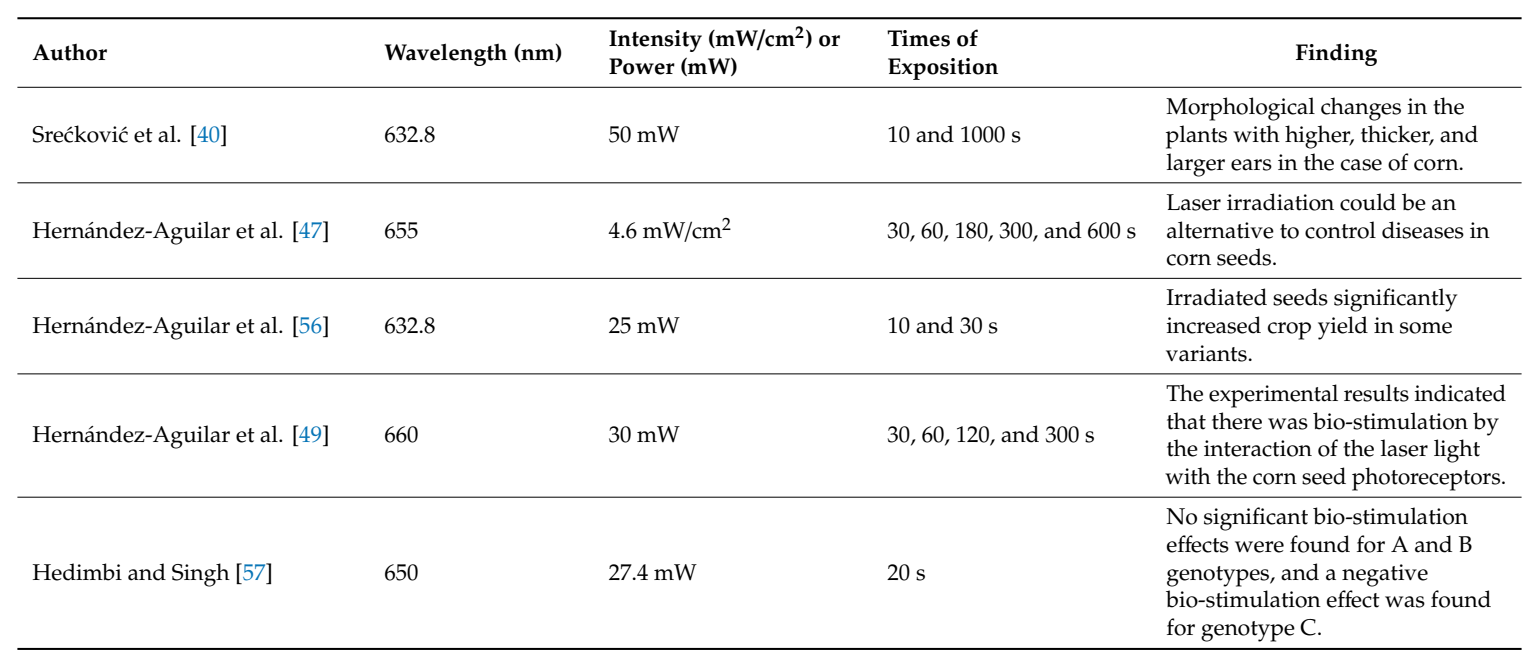


Table 3. Cont.

\begin{tabular}{|c|c|c|c|c|}
\hline Author & Wavelength (nm) & $\begin{array}{l}\text { Intensity }\left(\mathrm{mW} / \mathrm{cm}^{2}\right) \text { or } \\
\text { Power }(\mathrm{mW})\end{array}$ & $\begin{array}{l}\text { Times of } \\
\text { Exposition }\end{array}$ & Finding \\
\hline Samuilov and Garifullina [58] & 663 & $40 \mathrm{~W}$ & Every two hour & $\begin{array}{l}\text { Decrease in the height, diameter of } \\
\text { stem, and number of leaves in the } \\
\text { plants exposed to laser with the } \\
\text { increase in the time of exposure. }\end{array}$ \\
\hline Hernández-Aguilar et al. [59] & 632.8 & $50 \mathrm{~mW}$ & $0.60 \mathrm{~s}$ & $\begin{array}{l}\text { Effect of laser irradiation on } \\
\text { rotational correlation time } \\
\text { expressed in seconds in seed } \\
\text { endosperm was less pronounced } \\
\text { but also led to an increase in probe } \\
\text { mobility. }\end{array}$ \\
\hline Asghar et al. [60] & 650 & $3.04 \mathrm{~mW} / \mathrm{cm}^{2}$ & $15,30,45$, and $60 \mathrm{~s}$ & $\begin{array}{l}\text { The experimental results showed } \\
\text { that the interaction between the } \\
\text { laser light and maize seeds } \\
\text { affected the carotenoid content in } \\
\text { the leaves of seedlings. }\end{array}$ \\
\hline
\end{tabular}

\section{Conclusions}

The effects of different laser wavelengths, exposure times, and low-power-intensity laser irradiation on maize seeds were determined. It can be concluded that the pre-sowing laser treatment of seeds had a positive impact on the growth and development of maize plants. The plants grown from the irradiated seeds by the blue laser at $85 \mathrm{~s}$ reached a significantly higher plant height compared to plants grown at different wavelengths and to non-irradiated seeds. The irradiation of the sowing material had a positive influence on the seed yield of maize. An increase in yield was found for the seeds irradiated by the blue laser at $85 \mathrm{~s}$, followed by the green laser at $65 \mathrm{~s}$.

Author Contributions: Formal analysis, M.H.; writing—original draft preparation, M.H.; writing-review and editing, M.M.H., Z.A.T., I.H.H.A., and M.N.M.S.; supervision, M.M.H., Z.A.T., and I.H.H.A.; funding acquisition, M.M.H. All authors have read and agreed to the published version of the manuscript.

Funding: The APC was funded by DIP-2019-001 grant.

Acknowledgments: Marlia M. Hanafiah was supported by the Universiti Kebangsaan Malaysia (DIP-2019-001) and the Ministry of Education Malaysia (FRGS/1/2018/WAB05/UKM/02/2).

Conflicts of Interest: The authors declare no conflicts of interest.

\section{References}

1. El-Naggar, A.Y.; Shetaia, Y.M.; Youssef, K.A.; Ismail, N.A. Stimulation of the hydrocarbon compounds degrading Saccharomyces rosinii by low power laser radiation. Der Pharma Chem. 2012, 4, 1424-1434.

2. Jia, Z.; Duan, J. Protecting effect of He-Ne laser on winter wheat from UV-B radiation damage by analyzing proteomic changes in leaves. Adv. Biosci. Biotechnol. 2013, 4, 823. [CrossRef]

3. Aladjadjiyan, A. Physical factors for plant growth stimulation improve food quality. In Food production-approaches, challenges and tasks. Intech Croat. 2012, 270, 145-168.

4. Hernandez, A.C.; Dominguez, P.A.; Cruz- Orea, A.; Ivanov, R.; Carballo, C.A.; Zepeda, B.R. Laser in agriculture (Review). Int. Agrophys. 2010, 24, 407-422.

5. Reyes, M.C.P.; Hernandez-Aguilar, C.; Dominguez-Pacheco, A.; Cruz-Orea, A.; Martínez, E.M. The optical absorption coefficient of barley seeds investigated by photoacoustic spectroscopy and their effects by laser biostimulation. Int. J. Thermophys. 2015, 36, 2389-2400. [CrossRef]

6. Vasilevski, G. Perspectives of the application of biophysical methods in sustainable agriculture. Bulg. J. Plant Physiol. 2003, 29, 179-186.

7. Hasan, M.; Ismail, B.S. Effect of gibberellic acid on the growth and yield of groundnut (Arachis hypogaea L.). Sains. Malays. 2018, 47, 221-225. 
8. Tang, Z.; Yu, J.; Xie, J.; Lyu, J.; Feng, Z.; Dawuda, M.M.; Liao, W.; Wu, Y.; Hu, L. Physiological and Growth Response of Pepper (Capsicum annum L.) Seedlings to Supplementary Red/Blue Light Revealed through Transcriptomic Analysis. Agronomy 2019, 9, 139. [CrossRef]

9. Jevtic, S.D.; Sreckovic, M.Z.; Pelemis, S.S.; Konstantinovic, L.M.; Jovanic, P.B.; Petrovic, L.D.; Dukic, M.M. Laser influence to bio-systems. Hem. Ind. 2015, 69, 433-442. [CrossRef]

10. Ćwintal, M.; Dziwulska-Hunek, A.; Wilczek, M. Laser stimulation effect of seeds on quality of alfalfa. Int. Agrophys. 2010, 24, 15-19.

11. Maucieri, C.; Barco, A.; Borin, M. Compost as a Substitute for Mineral N Fertilization? Effects on Crops, Soil and N Leaching. Agronomy 2019, 9, 193. [CrossRef]

12. Farivar, S.; Malekshahabi, T.; Shiari, R. Biological effects of low level laser therapy. J. Lasers Med. Sci. 2014, 5, 58-62. [PubMed]

13. Smalley, P.J. Laser safety: Risks, hazards, and control measures. Laser Ther. 2011, 20, 95-106. [CrossRef]

14. Hasan, M. Effect of rhizobium inoculation with phosphorus and nitrogen fertilizer on physico-chemical properties of the groundnut soil. Environ. Ecosyst. Sci. 2018, 2, 4-6. [CrossRef]

15. Harun, S.N.; Mohd Hanafiah, M. Estimating the country-level water consumption footprint of selected crop production. Appl. Ecol. Env. Res. 2018, 16, 5381-5403. [CrossRef]

16. Joshi, S.; Joshi, G.; Agrawal, H. Study on the effect of laser irradiation on wheat (Triticum aestivum L.) variety PBW-373 seeds on zinc uptake by wheat plants. J. Radioanal. Nucl. Chem. 2012, 294, 391-394. [CrossRef]

17. Khalifa, N.S.; El Ghandoor, H. Investigate the effect of Nd-Yag laser beam on soybean (Glycin max) leaves at the protein level. Int. J. Biol. 2011, 3, 135. [CrossRef]

18. Kouchebagh, S.B.; Farahvash, F.; Mirshekari, B.; Arbat, H.K.; Khoei, F.R. Seed priming techniques may improve grain and oil yields of sunflower (Helianthus annuus L.). J. Anim. Plant Sci. 2014, 24, 1863-1868.

19. Li, J.; Guo, X.; Zhang, Y.; Ge, G.; Wang, Y.; Hou, Y.; Peng, J. Influence of He-Ne laser pretreatment on physiological characteristics in wheat seedlings under cadmium stress. Acta Bot. Boreali Occident. Sin. 2013, 33, 2474-2478.

20. Maamoun, M.K.M.; El-Mahrouk, M.E.; Dewir, Y.H.; Omran, S.A. Effect of radiation and chemical mutagens on seeds germination of black cumin (Nigella sativa L). J. Agric. Technol. 2014, 10, 1183-1199.

21. Jakubiak, M.; Gdowska, K. Innovative environmental technology applications of laser light stimulation. Енергетика I Автоматика 2013, 3, 14-21.

22. Álvarez, A.; Ramírez, R.; Chávez, L.; Camejo, Y.; Pompa, R. Agricultural yield in tomato plants (Solanum lycopersicum L.), from seeds treated with low-power laser. Rev. Granma Cienc. 2013, 17, 1-8.

23. Qiu, Z.; Li, J.; Zhang, M.; Bi, Z.; Li, Z. He-Ne laser pretreatment protects wheat seedlings against cadmium-induced oxidative stress. Ecotoxicol. Environ. Saf. 2013, 88, 135-141. [CrossRef]

24. Muszyñski, S.; Gadyszewska, B. Representation of He-Ne laser irradiation effect on radish seeds with selected germination indices. Int. Agrophys. 2008, 22, 151-157.

25. Podleśna, A.; Gładyszewska, B.; Podleśny, J.; Zgrajka, W. Changes in the germination process and growth of pea in effect of laser seed irradiation. Int. Agrophys. 2015, 29, 485-492. [CrossRef]

26. Wilczek, M.; Koper, R.; Cwintal, M.; Kornillowicz-Kowalska, T. Germination capacity and the health status of red clover seeds following laser treatment. Int. Agrophys. 2004, 18, 289-294.

27. Chen, Y.P.; Liu, Y.J.; Wang, X.L.; Ren, Z.Y.; Yue, M. Effect of microwave and He-Ne laser on enzyme activity and biophoton emission of isatis indigotica fort. J. Integr. Plant Biol. 2005, 47, 849-855. [CrossRef]

28. Ćwintal, M.; Dziwulska-Hunek, A. Effect of electromagnetic stimulation of alfalfa seeds. Int. Agrophys. 2013, 27, 391-401. [CrossRef]

29. Podleśny, J.; Stochmal, A.; Podleśna, A.; Misiak, L.E. Effect of laser light treatment on some biochemical and physiological processes in seeds and seedlings of white lupine and faba bean. Plant Growth Regul. 2012, 67, 227-233.

30. Wilczek, M.; Koper, R.; Cwintal, M.; Kornillowicz-Kowalska, T. Germination capacity and health status of hybrid alfalfa seeds after laser treatment. Int. Agrophys. 2005, 19, 257.

31. Kannan, M.; Ismail, I.; Bunawan, H. Maize Dwarf Mosaic Virus: From Genome to Disease Management. Viruses 2018, 10, 492. [CrossRef] [PubMed]

32. Juanssilfero, A.B.; Jahim, J.M.; Mutalib, F.A.A.; Zulkifli, W.Z.W.; Bakar, F.D.A.; Hassan, O. Characterization of copolymer Dehypon®LS 54 and its application for aqueous two-phase systems paired with the waxy maize starch for protein extraction. Int. J. Adv. Sci. Eng. Inf. Technol. 2011, 1, 65-71. [CrossRef] 
33. Aguilar, C.H.; Pacheco, F.A.D.; Orea, A.C.; Tsonchev, R.I. Thermal effects of laser irradiation on maize seeds. Int. Agrophys. 2015, 29, 147-156. [CrossRef]

34. Metwally, S.A.; Abou-Ellail, M.; Abo-Leila, B.H.; Aboud, K.A. Effect of laser radiation on the growth, anatomical and biochemical genetic markers of celosia argentea plants. Int. J. Acad. Res. 2013, 5, 200-206. [CrossRef]

35. Śliwka, M. Assessment of impact of coherent light on resistance of plants growing in unfavourable environmental conditions. Ecol. Eng. 2014, 15, 112-118.

36. Rimal, B.; Ranaivoson, R.M.; Czarnecka, K.P.; Dobrowolski, J.W. Laser biotechnology for enhanced rooting and shooting of Salix viminalis in hydroponic condition for better adaptation in industrially contaminated land. Int. J. Environ. Bioremediat. Biodegrad. 2014, 2, 228-230.

37. Hoseini, M.; Feqenabi, F.; Tajbakhsh, M.; Babazadeh-Igdir, H. Introduction of seed treatment techniques (seed priming). Int. J. Biosci. 2013, 3, 1-12.

38. Elsahookie, M.M.; Wuhaib, K.M. Performance of clipped maize. J. Agron. Crop Sci. 1988, 160, 10-13. [CrossRef]

39. Ashrafijou, M.; Noori, S.S.; Darbandi, A.I.; Saghafi, S. Effect of salinity and radiation on proline accumulation in seeds of canola (Brassica napus L.). Plant Soil Environ. 2010, 56, 312-317. [CrossRef]

40. Srećković, M.; Vasić, R.; Dukić, M.; Jevtić, S.; Jovanić, P. The influence of diode and He-Ne Lasers on corn and wheat seeds. J. Agric. Sci. Technol. B 2014, 4, 165-175.

41. Hernandez-Aguilar, C.; Dominguez-Pacheco, A.; Cruz-Orea, A. Thermal changes of maize seed by laser irradiation. Int. J. Thermophys. 2015, 36, 2401-2409. [CrossRef]

42. Sanchez-Hernandez, G.; Hernandez-Aguilar, C.; Dominguez-Pacheco, A.; Cruz-Orea, A.; Perez-Reyes, M.C.J.; Martinez, E.M. The optical absorption coefficient of bean seeds investigated using photoacoustic spectroscopy. Int. J. Thermophys. 2015, 36, 835-843. [CrossRef]

43. Abu-Elsaoud Abdelgaphafar, M.; Tuleukhanov, S.T. Can He-Ne laser induce changes in oxidative stress and antioxidant activities of wheat cultivars from Kasakhstan and Egypt? Sci. Int. 2013, 1, 39-50.

44. Muthusamy, A.; Kudwa, P.P.; Prabhu, V.; Mahato, K.K.; Babu, V.S.; Rao, M.R.; Gopinath, P.M.; Satyamoorthy, K. Influence of Helium-Neon laser irradiation on seed germi-nation in vitro and physico-biochemical characters in seedlings of Brinjal (Solanum melongena L.) var. Mattu Gulla. Photochem. Photobiol. 2012, 88, 1227-1235. [CrossRef]

45. Álvarez, A.; Ramírez, R.; Chávez, L.; Camejo, Y. Effect of the treatment of seeds with radiation laser of fall promotes in a hybrid of tomato (Solanum lycopersicum L.). Rev. Granma Cienc. 2011, 15, 1-9.

46. Michtchenko, A.; Hernández, M. Photobiostimulation of germination and early growth of wheat seeds (Triticum aestivum L) by a $980 \mathrm{~nm}$ semiconductor laser. Rev. Cuba. Física 2010, 27, 271-274.

47. Hernandez-Aguilar, C.; Liliana, R.P.C.; Arturo, D.P.F.; María, H.A.A.; Alfredo, C.O.; Aquiles, C.C. Laser light on the mycoflora content in maize seeds. Afr. J. Biotechnol. 2011, 10, 9280-9288.

48. Abdullateef, R.A.; Osman, M. Effects of visible light wavelengths on seed germinability in Stevia rebaudiana Bertoni. Int. J. Biol. 2011, 3, 83.

49. Hernandez-Aguilar, C.; Dominguez-Pacheco, A.; Cruz-Orea, A.; Ivanov, R.; Carballo-Carballo, A.; Zepeda-Bautista, R.; Galindo Soria, L. Laser irradiation effects on field performance of maize seed genotypes. Int. Agrophys. 2009, 23, 327-332.

50. Mathews, M.A.; Pai, B.J.; Benedicenti, S. Effect of photobiomodulation on osseointegration and bone-A review. J. Laser Appl. 2015, 27, 012003. [CrossRef]

51. Levskaya, A.; Weiner, O.D.; Lim, W.A.; Voigt, C.A. Spatiotemporal control of cell signalling using a light-switchable protein interaction. Nature 2009, 461, 997. [CrossRef] [PubMed]

52. Bouly, J.P.; Schleicher, E.; Dionisio-Sese, M.; Vandenbussche, F.; Van Der Straeten, D.; Bakrim, N.; Ahmad, M. Cryptochrome blue light photoreceptors are activated through interconversion of flavin redox states. J. Biol. Chem. 2007, 282, 9383-9391. [CrossRef]

53. Jamil, Y.; Perveen, R.; Ashraf, M.; Ali, Q.; Iqbal, M.; Ahmad, M.R. He-Ne laser-induced changes in germination, thermodynamic parameters, internal energy, enzyme activities and physiological attributes of wheat during germination and early growth. Laser Phys. Lett. 2013, 10, 45-60. [CrossRef]

54. Dobrowolski, J.W.; Śliwka, M.; Mazur, R. Laser biotechnology for more efficient bioremediation, protection of aquatic ecosystems and reclamation of contaminated areas. J. Chem. Technol. Biotechnol. 2012, 87, 1354-1359. [CrossRef] 
55. Rassam, Y.Z. The Effect of laser light on virulence factors and antibiotic susceptibility of locally isolated Pseudomonas aeruginosa. J. Appl. Sci. Res. 2010, 6, 1298-1302.

56. Hernandez-Aguilar, C.; Cruz-Orea, A.; Ivanov, R.; Martínez, E.S.M.; Michtchenko, A. Photoacoustic spectroscopy applied to the study of the influence of laser irradiation on corn seeds. Int. J. Phys. IV (Proc.) 2005, 125, 853-855. [CrossRef]

57. Hedimbi, M.; Singh, S. Laser induced fluorescence study on the growth of maize plants. Nat. Sci. 2012, 4, 395. [CrossRef]

58. Samuilov, F.D.; Garifullina, R.L. Effect of laser irradiation on microviscosity of aqueous medium in imbibing maize seeds as studied with a spin probe method. Russ. J. Plant Physiol. 2007, 54, 128. [CrossRef]

59. Hernandez-Aguilar, C.; Carballo, A.C.; Cruz-Orea, A.; Ivanov, R.; Domínguez-Pacheco, A. The carotenoid content in seedlings of maize seeds irradiated by a 650nm diode laser: Qualitative photoacoustic study. Eur. Phys. J. Spec. Top. 2008, 153, 515-518. [CrossRef]

60. Asghar, T.; Jamil, Y.; Iqbal, M.; Abbas, M. Laser light and magnetic field stimulation effect on biochemical, enzymes activities and chlorophyll contents in soybean seeds and seedlings during early growth stages. $J$. Photochem. Photobiol. B 2016, 165, 283-290. [CrossRef]

(C) 2020 by the authors. Licensee MDPI, Basel, Switzerland. This article is an open access article distributed under the terms and conditions of the Creative Commons Attribution (CC BY) license (http://creativecommons.org/licenses/by/4.0/). 